\title{
Tax Incentives and the Growth in Sales Revenue of Small and Medium Enterprises (SMEs) in Ondo and Ekiti States, Nigeria
}

\author{
Babatayo Kolawole Olayemi, Adegbie Festus Folajimi \\ Department of Accounting, Babcock University, Ilishan Remo, Nigeria \\ Email address: \\ Kobabatayo@gmail.com (B. K. Olayemi), Adegbief@babcock.edu.ng (A. F. Folajimi) \\ To cite this article: \\ Babatayo Kolawole Olayemi, Adegbie Festus Folajimi. Tax Incentives and the Growth in Sales Revenue of Small and Medium Enterprises \\ (Smes) in Ondo and Ekiti States, Nigeria. International Journal on Data Science and Technology. Vol. 7, No. 1, 2021, pp. 1-16. \\ doi: $10.11648 /$ j.ijdst.20210701.11
}

Received: August 20, 2020; Accepted: September 11, 2020; Published: January 4, 2021

\begin{abstract}
The growth of Small and Medium Scale Enterprises (SMEs) had been considered a vital factor in the economic development of any country especially with regard to creation of employment and contribution to the growth of Gross Domestic Product. The growth of SMES was however hindered by challenges ranging from the lack of financial resources to expand, inadequate infrastructural facilities, lack of support from the government, harsh business environment, and above all, unpleasant taxation policy of the government creating enormous tax burdens to the SMEs. Tax Incentives had been perceived to influence the growth of small and medium enterprises (SMEs). In the light of all these, this paper reviewed the effect of tax incentives on the growth in sales revenue of Small and Medium Enterprises in Ondo and Ekiti States, Nigeria. The study employed survey design. The study population comprised SMEs registered with Small and Medium Enterprise Development Agency of Nigeria in Ondo and Ekiti States, with the total of 2,708. The Taro Yamane formula was used to obtain a sample size of 386. The owners/managers, employees, accountants and auditors of these SMEs were selected through a multi-stage sampling technique which involved the stratified, proportionate, and simple random sampling methods. Descriptive and inferential statistics were used to analyse the data. The results showed tax incentives (investment allowance, tax holiday, tax credit and tax deferment) have a significant positive effect on the growth in sales revenue of SMEs, $F_{679}=313.815$, Adj $_{\text {. }}$ $R^{2}=0.759, p$-value $=0.000<0.05$. Hence, the study concluded that tax incentives proxies, of investment allowance, tax holiday, tax credit and tax deferment were significant determinants of the growth in sales revenue of SMEs in Ondo and Ekiti States, Nigeria.
\end{abstract}

Keywords: Sales Revenue, Investment Allowance, Tax Credit, Tax Deferment, Tax Holiday

\section{Introduction}

\subsection{Background}

The Small and Medium Enterprises (SMEs) are the backbone of any major developed economy, as well as important contributors to employment, economic and export growth. Agwu [4] opines that SMEs remain the foundation as well as the building block in the realization of any meaningful and sustainable growth in an economy and constitute the driving force in the attainment of industrial growth and development. This is basically due to their great potential in ensuring diversification and expansion of industrial production as well as the attainment of the basic objectives of growth [4]. For sustainable economy, according to Udofot and Etim [53], SMEs have been stressed as capable of helping in bringing about positive economic turn around and complementing the effort of the existing large scales industries. Peace and Ezejiofor [42], opine that the recognition of the importance of the roles of the SMEs as the pillar of growth has prompted the increased attention and specific education on the method and approach to build and sustain a truly viable private sector dominated by small and medium scale enterprises (SMEs) not only in Nigeria but also in other developing and developed economies. The growth of SMEs is therefore an essential element in the development 
strategy of most economies and hold particular significance for Nigeria, a country with $23.1 \%$ unemployment rate of the available workforce [34].

World over, governments have increasingly focused on the growth of SMEs by introducing several measures aimed at developing the sector. Liu [30] opined that with the opening up of China to market economy in the 1980s, China was able to solve significantly, the issue hindering the growth of SMEs in the country. This was achieved by the Chinese government through the introduction of several reforms which included but not limited to an array of policy incentives comprising fiscal, tax and financial incentives. Xinhu [55] further opined, that between the year 1980 and 2018, SMEs growth has been boosted and has increasingly contributed to China economic growth consisting of $99 \%$ of all enterprises in China today and the output of SMEs accounts for at least $60 \%$ of the country's GDP generating more than $82 \%$ of employment in China. According to Audretsch [8], the SMEs in the EU is said to have provided two-thirds of the total private sector employments and in the United States of America (USA), SMEs employ about $50 \%$ of the workforce and generate more than half of the nation's Gross Domestic Products. According to a report by the European Union (EU), SMEs serve as the backbone of Europe's economy accounting for $99 \%$ of all businesses in the EU in the past five years and have contributed around $85 \%$ of new jobs.

In Africa, Kongolo [28] cited in Udofot and Etim [53] opined that SMEs were known to account for about $91 \%$ of the formal businesses, contributing about $51 \%$ to $57 \%$ of GDP, providing almost $60 \%$ of employments. However, in Nigeria, the International Financial Corporation (IFC) has shown that, even though, approximately, 96\% of Nigerian businesses are SMEs compared to $53 \%$ in the US and $65 \%$ in Europe, yet, SMEs in Nigeria contribute approximately only $40 \%$ of GDP compared to $50 \%$ in the US or Europe. Several factors have been considered as the impediments slowing the growth of SMEs in Nigeria. Key among these factors according to Udofot and Etim [53], include: insufficient capital, irregular power supply, infrastructural inadequacies (water, roads etc.), multiple taxation, capital shortage, taxation and regulations, product liability patent and franchising abuses. Hence, according to the Small and Medium Scale Enterprises Development Agency of Nigeria (SMEDAN) [46], $80 \%$ of SMEs in Nigeria fold up before their 5 th anniversary.

Ekpenyong [19] opines that insufficient capital, irregular power supply, infrastructural inadequacies (water, roads etc.), multiple taxation, capital shortage, taxation and regulations, product liability patent and franchising abuses were some of the factors responsible for the untimely fold up on SMEs in Nigeria. Ojochogwu and Ojeka [41] also stated that among the factors responsible for untimely fold up of SMEs are tax related issues ranging from complex taxation to enormous tax burden. Complex taxation seems to be a major threat to the growth of SMEs especially in less industrialized countries like Nigeria. Agot and Ugwuoke [3] supported this view when they opined that complex tax systems put disproportionate pressure on smaller business as SMEs resources directed towards multiple tax compliance are resources that could otherwise be used for re-investment to promote future growth. According to Egbesola (18), SMEs are suffocating under multiple tax regimes observed across the various tiers of government. Consequently, Twesige and Gashega [52] opined that it is assumed that businesses would consider tax implications in their calculation of the value of their expenditures as well as the sales price of their products since any reduction in the cost of capital caused by tax policy leads to an equal increase in expenditure.

Therefore, in a bid to encourage and stimulate the growth of revenue accruable to the SMEs, several countries have used tax incentives to promote sales revenue of the SMEs by lowering cost of sales through the use of tax incentives. The tax incentives such as; investment allowance, tax holidays, tax credit and tax deferment among others have been used by governments to stimulate the growth of sales revenue of SMEs. According to Mintz and Chen [24], tax incentives for investors are the more common approach, particularly in advanced markets. For instance, Poland adopted the policy of encouraging investment in shares of SMEs through removing so-called "back-end" taxes, which are the taxes applied to profits made when selling a security [15]. In India, investors benefit from reduced capital gains taxes on SME equity investments [12]. This is done via the cutting of short-term capital gains tax in half, from 30 to $15 \%$, for shares listed of SMEs [52]. In the UK and Spain, governments adopted a tax incentive policy where the retail investors may deduct a set percentage of the value they invest in shares of SME equity [47]. This happens via offering tax offsets only for acquiring shares in new SME equity offerings.

In Africa, according to Kaplan [26], Zimbabwe government provides investment incentives with six objectives in mind: Employment creation; small business development; industrial development; export promotion; spatial development; and up-liftment of the disadvantaged. These incentives according to Kaplan [19] take the form of financing arrangements, which operate through the Ministry of Industry and International Trade (MIIT) and the Industrial Development Corporation and the Zimbabwe Investment Centre (IDCZIC). In Nigeria, a country that is faced with serious youths' unemployment rate of around 23\% [34], Small and Medium Enterprises are expected to facilitate the growth and development of human and capital resources towards general economic development and the rural sector in particular. However, the mortality rate of these small and medium scale enterprises is very high. According to the Small and Medium Scale Enterprises Development Agency of Nigeria (SMEDAN) [46], $80 \%$ of SMEs fold up before their 5th anniversary. The effect of SMEs folding up due to an array of impediments as earlier mentioned portends a very dangerous trend to the Nigerian economy and is also devastating as it worsens the already high unemployment rate due to loss of jobs, assets as well as the Gross Domestic Product (GDP).

Despite of the importance of sustaining the growth of 
SMEs as a way of boosting the country's economy, studies solely focusing on the effect of tax incentives on the growth of sales revenue of SMEs businesses in developing countries particularly Nigeria as it relates to Ondo and Ekiti States seem to be very limited and scarce. For instance, Atawodi and Ojeka [9] research was on "Relationship between Tax Policy, Growth of SMEs and The Nigerian Economy". The research found a negative relationship between tax and a small business ability to sustain itself rather on how tax incentives affect the growth of SMEs. Moreover, the study failed to explain the indices used in measuring the growth of SMEs in the study. Agwu [4] was on "Issues, Challenges and Prospects of SMEs in Porthacourt City, Nigeria". Udofot and Etim [53] in the other hand, was on "The Effect of Tax Revenue Components from SMEs on the Economic Growth of Nigeria from 1980-2015". Also, Agot and Ugwuoke [3] study was on "Taxation and Growth of SMEs in Nigeria: A Case Study of Selected SMEs in Nasarawa State". These studies failed to address the issue of tax incentives as they affect the growth in sales revenue of SMEs businesses in Nigeria. Other studies carried out outside Nigeria such as Twesige and Gashega [52] focused solely on tax incentives given to the SMEs investors by the government rather than tax incentives offered to the SMEs businesses. It is within the context of the identified gap that the study will examine the effect of tax incentives on the growth of sales revenue of SMEs businesses in Ondo and Ekiti.

\subsection{Statement of the Problem}

In Nigeria, SMEs have not performed commendably well as they have not adequately played the expected significant role in the economic growth of the nation [50]. This is because small and medium scale businesses are faced with the challenges of high tax rates, multiple taxations, intricate tax regulations and deficiency in proper enlightenment about tax related issues [36]. The effect of this includes the high rate of poverty and increase in the cost of production and ultimately leads to increase in the sales price. Therefore, if a large proportion of SME costs are devoted to paying tax, the SMEs will be forced to transfer the tax burden onto the consumers, and as a result, this will ultimately make their goods and services uncompetitive, which tends to have a negative impact on their sales revenue [25].

The mortality rate of the SMEs in Nigeria is also very high [5]. According to Aremu and Adeyemi [6], most SMEs in Nigeria die within their first five years of existence, a smaller percentage goes into extinction between the sixth and tenth year while only about five to ten percent survive, thrive and grow to maturity. This view was supported by the Small and Medium Enterprises Development Agency of Nigeria (SMEDAN) [46] that $80 \%$ of SMEs die before their $5^{\text {th }}$ anniversary. Among the factors responsible for these untimely close-ups are tax related issues, ranging from multiple taxations; lack of funds; lack of infrastructural facilities; lack of support from the government; harsh business environment; and enormous tax burdens. This view was supported by Basil [11] cited in Agwu [4] where they believed that the key factors among these factors include: insufficient capital, irregular power supply, infrastructural inadequacies (water, roads etc.), lack of focus, inadequate market research, over-concentration on one or two markets for finished products, lack of succession plan, lack of proper book keeping, in ability to separate business and family or personal finances and cut-throat competition.

In a developing country like Nigeria, there is an urgent need to provide the required enabling environment for the growth of SMEs, so that they could adequately play the role expected of them in the economic transformation of Nigeria. Such roles include mobilization of domestic savings for investment; increased harnessing of local raw materials; appreciable contribution to gross domestic product; employment generation, and significant contribution to poverty reduction efforts through sustainable livelihoods and enhancement in staff income, technological advancement and export diversification [43]. However, this is not the case in Nigeria because taxes which are levied for regulating the investment behaviour of the investors are discouraging the entrepreneurial growth and development, and this thus serves as a major constraint to the development of the SMEs in Nigeria. Complex taxation has been deemed to be a major threat to the growth of SMEs especially in less industrialized countries.

In Nigeria, taxes imposed on SMEs range from direct tax which includes income tax charged on business income, employment income; rent income, and investment income to indirect taxes such as Value Added Tax (VAT), Corporation tax and excise duties. All these taxes have tendencies of slowing the growth of SMEs as they increase the costs of operation of running SMEs. In order to recoup the increased costs of operation, the SMEs raise the prices of goods thereby causing volume of sales to go down due to stiff competition from imported goods. The effects of reduced sales are reduced profits, reduced capital base and slow creation of employment resulting to slow growth and increased poverty.

Lack of knowledge on the part of the SMEs operators as to the availability of various tax incentives that could boost the revenue of their businesses is also a major concern. It is believed that tax incentives encourage economic growth and industrial development of SMEs [18].

\subsection{Objectives of the Study}

The main objective of this study is to examine the effect of tax incentives on the growth of SMEs in Ondo and Ekiti States, Nigeria. And specifically to evaluate the effect of tax incentives on the growth in sales revenue of SMEs in Ondo and Ekiti States, Nigeria.

\subsection{Hypothesis}

The hypothesis tested in this study is:

Ho1: There is no significant effect of tax incentives on the growth in sales revenue of SMEs in Ondo and Ekiti States, Nigeria. 


\section{Literature Review}

\subsection{Conceptual Review - Small and Medium Scale Enterprises (SMEs)}

According to extant literature, the definition of SMEs varies in different economies but the underlying concept is the same. Fatai [20] argues that the concept of SMEs cannot be explained other than to say they are companies with metric (usually number of employees or annual turnover that fall below certain threshold). It is these indicators, number of employees and or rate of turnover that tend to define the context within which different countries and economies situate their understanding of small and medium scale enterprises. Adeyemi [8] believes that the characterization of SMEs varies in different economies although the core concept is similar. According to Okonkwo and Obidike [38], the meaning given to small and medium enterprises differs in accordance with country, schools, context, scholars and author. Nwakoby, Ajike and Ezejiofor [35] in the other hand notes that the definition and criteria for classification of an enterprise as small, medium or large varies from one country to another, depending on whether it is developed or developing country.

For instance, Fatai [20] opines that in Britain, small scale business is conceived as that industry with annual turnover of 2 million pounds or less with fewer than 200 paid employees. In Japan, SMEs is conceptualized as type of industry, with paid up capital and number of employees categorized into manufacturing company with 100million yen paid up capital and 300 employees [20]. Those in wholesale trade with 300 million yen paid up capital with 100 employees while those in retail trade with 100 million yen paid up capital with 50 employees [20]. In other countries, SMEs are defined in term of the industry and nature of businesses [24]. In Nigeria case, it may be said that there is no clear-cut definition that distinguishes small and medium scale enterprises. The classification and definition of the concept of SMEs in Nigeria has passed through many stages.

The International Finance Corporation (IFC) according to Feyitimi, Temitope, Akeem and Oladele [21] define small enterprises as those that meet two of the following three conditions: (i) less than 50 employees, (ii) Less than $\$ 3$ million total assets and (iii) less than $\$ 3$ million total annual sales, while, medium enterprises are those that meet two of the following three conditions: (i) Less than 300 employees, (ii) less than $\$ 15$ million total assets and (iii) less than $\$ 15$ million total annual sales. Due to the different definitions ascribed to SMEs in Nigeria, the National Policy on Micro, Small and Medium Enterprises (MSMEs) was issued in 2013 to address the issue of definition as to what constitutes micro, small and medium enterprises. The definition adopts a classification based on dual criteria, employment and assets (excluding land and buildings) as shown in table 1.

Table 1. Definition of MSMEs by National Policy on MSMEs.

\begin{tabular}{llll}
\hline S/N & Size Category & Employment & Assets (=N=Million Excluding Land And Buildings) \\
\hline 1 & Micro Enterprises & Less than 10 & Less than 5 \\
2 & Small Enterprises & $10-49$ & 5 to less than 50 \\
3 & Medium Enterprises & $50-199$ & 50 to less than 500 \\
\hline
\end{tabular}

Source: SMEDAN (2015).

The policy further states that if there exists a conflict on classification between employment and assets criteria (for example, if an enterprise has assets worth seven million naira (N7M) but employs 7 persons), the employment-based classification will take precedence and the enterprise would be regarded as micro. The Nigeria Finance Act 2020 adopted turnover as the basis for classification of companies for company income tax purposes. The Act classifies small enterprises as those who annual turnover does not exceed N25million while medium size companies are those whose annual turnover fall within $\mathrm{N} 25 \mathrm{~m}$ to $\mathrm{N} 100 \mathrm{~m}$ and large companies as those whose annual turnover exceed N100m. This article however, adopted the definition criteria used by the National Policy on Micro, Small and Medium Enterprises (MSMEs) in classifying the SMEs.

\subsection{Tax Incentives}

Tax incentives have been defined in various ways by different scholars $[49,37]$. Tax incentives have been described as exemption or reliefs granted to an individual or a company to reduce the effect of taxation and thus encourage savings and investment. Okauru [37] noted further that the reality of tax incentives in Nigeria is that not many people truly take advantage of the incentives that exist, and even when they do, past trends have suggested an individual corporate approach rather than an industry-wide approach. Also, Keen [27] defines tax incentives as all measures and strategies which provide for more favourable tax treatment to a certain activities or sector, and he went on to describe the following to be typical tax incentives: (i) tax holidays which is defined as the temporal exemption of business investment from certain specified taxes, typically at least corporate income tax. Partial tax holidays offer the reduced obligations rather than full exemption, (ii) special zones which are placed in geographically limited areas where qualified companies can locate and hence benefit from the exemption of various scopes of taxes or administrative requirements, (iii) investment tax credit which is the deduction of some fraction of an investment from the tax liability, (iv) investments allowance/accelerated depreciation which is the deduction of some fraction of an investment from taxable profits (in addition to depreciation), (v) reduced tax rates/preferential tax rates which are the reductions in a tax rate, specifically the corporate income tax rate, (vi) exemptions from various taxes which are the exemptions from certain 
taxes, most of the time those collected at the border such as tariffs, excises and VAT on imported inputs, (vii) financing incentives which are the reductions in tax rates for the funds providers for example: the reduced withholding taxes on dividends and (viii) Loss carried forward which is usually offered when the business makes a loss, the loss can be carried forward to offset the future.

It can therefore be easily inferred that tax incentives are tax reduction given to encourage or support specific course of action intended to encourage investment in certain sectors or geographical areas. Different countries use various forms of incentives which are suitable for the purpose it was meant for and in line with the economic realities. The tax incentives used in Nigeria as spelt out by the Nigeria Export Promotion Council (NEPC), in 2001 are.

\subsubsection{Investment Allowance}

Investment allowances are deductions from taxable income based on some percentages of new investment; it is used by the Nigerian government to encourage investment in some preferred sectors of the economy. According to Oyedele and Erukume [40] Investment Allowance is granted at the rate of $10 \%$ to corporate organization (companies) that incur expenditure on plant and equipment. It is calculated on cost and granted in the first year in which the asset is first to used. Olaleye, Memba, and Riro [39] state that the available investment allowance under the Nigerian tax system presently are: $10 \%$ investment allowance on plant and machinery for business in the agricultural sector; $10 \%$ investment allowance on production machinery in use by manufacturing concerns; and 15\% investment allowance on plant and machinery acquired as a replacement for obsolete ones. However, it should be noted that separate investment allowance tax relief is available to businesses which are located not less than $20 \mathrm{~km}$ away from the following facilities on infrastructure costs at the rate stated in table 2.

Table 2. Investment Allowance.

\begin{tabular}{ll}
\hline No facilities at all & $100 \%$ \\
No electricity & $50 \%$ \\
No water & $30 \%$ \\
No tarred (paved) road & $15 \%$ \\
\hline
\end{tabular}

Source: PWC Tax Data Card Nigeria (2015).

Bergner [12] referred to investment allowances as superdeductions, in contrast to special depreciation schemes, allow the deduction of a fixed percentage of eligible expenditures (e.g., personnel costs, costs of newly acquired assets) or balance sheet positions (e.g., shareholders' equity, special investment reserves) on top of the general allowances provided by the tax code. Unlike the schemes of accelerated depreciation, they decrease overall inter-periodic taxable income and induce a true reduction of tax payments instead of a pure interest advantage [27].

As a consequence, loss-making firms do not benefit if no refunds are available and if there are no opportunities to offset additional losses. Kiabel [27] is of the view that Investment Allowance is only available in the first year, and it is not deductible from the cost of the asset. Olaleye, Memba, and Riro [39] state that the available investment allowance under the Nigerian tax system presently are: $10 \%$ investment allowance on plant and machinery for business in the agricultural sector; $10 \%$ investment allowance on production machinery in use by manufacturing concerns; and $15 \%$ investment allowance on plant and machinery acquired as a replacement for obsolete ones.

\subsubsection{Tax Holidays}

Tax holidays are a common form of tax incentive used by developing countries and countries with economies in transition to attract investment in certain sectors. Under a tax holiday, qualifying newly established firms are exempted from paying corporate for about five years. The may include a tax holiday of three years initially, which may be extended for up to two years upon satisfaction of specified conditions. This is governed under the Nigerian Investment Promotion Commission Act [16]. The tax holiday further reviewed under the Pioneer Status Incentive Regulations, 2014. In the study carried out by Twesige and Gasheja [52], it was found that Tax holiday has a significant and positive relationship with the growth of SMEs $(b=0.664$, sig=0.056) indicating that $66.4 \%$ of the variation in the growth of SMEs is explained by tax holiday.

\subsubsection{Investment Tax Credit}

According to Adamu [2] Investment tax credit may be flat or incremental. Adamu [2] opines further that flat investment tax credit is earned as a fixed percentage on investment expenditure incurred in a year on qualifying capital. In contrast, an incremental investment tax credit is earned as a fixed percentage of qualifying expenditure in a year in excess of some bases that is typically a moving average base. Abdulrahman and Kabir [1] however, note that the investment tax credit is basically a tax related incentive that allows individuals or entities to deduct a certain percentage of specific investment related costs from their tax liability apart from usual allowances for depreciation. Uwuigbe, Uwuigbe, Adeyemo and Anowai [54] state that the investment tax credit, which was crafted for stimulating the economy condition of a country by way of encouraging capital related expenditure, has been granted varied amounts since the year 1962. In the year, 1985, it was six to ten percent of the purchasing price, based on an asset's life.

\subsubsection{Tax Deferment}

According to Ogbodo, Egbunike and Abiahu [41], tax deferment occurs when there is no tax due on income earned in the account. The opine further that the ability to defer taxes on the returns of investments benefits the SMEs in two ways-(i) the primary benefits come in the form of tax free growth which majorly involves an attempt to pay tax on the current returns of an investment at a future date thus allowing investment to grow without current tax implications.

\subsubsection{Sales Revenue}

This is the amount realized from the sale of goods and 
services in the operation of an enterprise in a specified period of time. According to Machek and Machek [31], growth is an important stage of lifecycle for all for-profit organizations. They are of the view that the sources of business growth have been subject to a considerable academic attention. Growth is a process function which happens over multiple time periods. The growth of firm can be represented by the change of some variable over time. Machek and Machek [31] opined that the most frequently used measures of growth are probably profit, physical output in natural units, sales in monetary units or market share. Base on the existing research, the growth of a firm can be measured by the growth of sales expressed in monetary units. Machek and Machek [31] further stated that sales growth can be measured by average bill (Asset turnover, labour productivity, labour intensity and capital intensity).

\subsection{Theoretical Review}

\subsubsection{The Benefit Theory}

The benefit theory was propounded by Eric Lindahl in the year 1919. The theory assumes that government has another source of funding infrastructure and the burden will now be passed to the citizen. The theory proceeds on the assumption that there is basically an exchange or contractual relationship between tax-payers and the state. The state provides certain goods and services to the members of the society and they contribute to the cost of these supplies in proportion to the benefits received [10]. In this quid pro quo set up, there is no place for issues like equitable distribution of income and wealth. Instead, the benefits received are taken to represent the basis for distributing the tax burden in a specific manner. Eric-1919 believed that if taxes are levied on this principle as stated, then justice can be achieved. The benefit theory as advocated by Eric-1919 was subjected to severe criticisms on the following grounds; (i) based on the benefit theory; it means that if tax revenue is used to finance the building of a primary school, a man who has no child should not pay the tax since he will not benefit from it. Taxation based on the benefit theory will not yield much revenue to the government since, as already stated, many people who can afford to pay heavy tax may end up paying less tax simply because they do not receive much benefit from government expenditure; (ii) if the state maintains a certain connection between the benefit conferred and the benefits served, it will be against the principle of tax as it is compulsory contribution made to the public authorities to meet the expense of the government and for the provision of general infrastructures to all and; (iii) another flaw of benefit theory is that most of the expenditures incurred by the state are for the general benefits of the citizen. As a result of this, it is impossible to estimate the benefit enjoyed by a particular individual every year.

\subsubsection{Ability to Pay Theory}

In its use for assessing the efficiency of taxes and appraising fiscal policy, the benefit to pay theory was initially developed by Knut Wicksell in 1896 and Eric Lindahl in 1919, who were economists of the Stockholm School. The theory was later extended in the work of Paul Samuelson and
Richard Musgrave. According to Anyanfo [7], this theory states that one should be taxed according to the ability to pay. It is simply an attempt to maximize an explicit value judgment about the distributive effects of taxes. This approach considers tax liability in its true form, that is, compulsory payment to the state without quid pro quo. It does not assume any commercial or semi-commercial relationship between the state and the citizens. The basic assumption of this theory is that the burden of taxation should be shared by the members of society on the principles of justice and equity and that these principles necessitates that the tax burden is apportioned according to their relative ability to pay. Both theorists opined that if the objective of the government is to redistribute income, it should set taxes according to the ability-to-pay principle. Bhartia [10] argued against the ability to pay theory where he opined that a citizen is to pay taxes just because he can and his relative share in the total tax burden is to be determined by his relative paying capacity. This doctrine has been in vogue for at least as long as the benefits theory. This theory was supported by socialist thinkers because of its conformity with the ideas and concepts of justice and equity. The doctrine also received an equally strong support from non-socialist thinkers also and became a part of the theory of welfare economics.

However, this theory was a subject of criticisms. The critic opined that it is difficult to measure ability. There are, in general, three measures of ability: income, expenditure and property which are; (i) income which is said to be a better measure of ability than wealth; (ii) expenditure, according to Prof. N. Kaldor, expenditure is the best possible measure of ability. He advocated an expenditure tax which was tried in India for some time but withdrawn subsequently. A poor man may spend more if he has more dependants and if he has to look after his old parents. So, his expenditure may be higher than his colleague belonging to the same income bracket. But his expenditure does not reflect his true ability to pay and; (iii) property, it is believed that possession of wealth or property is a reflection of well- being, but to a limited degree. For example, if two persons have the same amount of wealth, they are not equally well-off. One may have some productive wealth like a building which yields a steady income. Another may have unproductive wealth (i.e., jewelry) of the same value. Naturally, their ability to pay taxes will differ greatly.

\subsubsection{The Expediency Theory}

The theory also known as theory of necessity was developed by Bartial in 2009. The theory was based on the assumption that in designing a tax proposal by the tax authorities, the economic and social objectives of the state as also the effects of a tax system should be treated as irrelevant. This proposition is believed to be cogent because it is useless to have a tax which cannot be levied or collected efficiently. This is because there are pressures from economic, social and political groups. Every group tries to protect and promote its own interests and the authorities are often forced to reshape tax structure in order to accommodate the pressures. In 
addition, the administrative set up may not be efficient enough to collect the tax at a reasonable cost of collection.

Buehler [14], on the other hand opined that expediency in tax theory is the principle of taxing as circumstances seem to warrant and with chief regard to the more immediate, practical and pressuring considerations. He stated further that an expedient tax policy may be the wisest and best under the circumstances, or it may merely be the policy of temporizing with an issue and following the path of least resistance.

The expediency theory however was also criticized on the following grounds; (i) critics believe that the theory of expediency appears to be unscientific and therefore, its influence on tax action has not always been fully appreciated; (ii) critics believe that taxation provides a powerful set of policy tools to the authorities and should be effectively used for remedying economic and social ills of the society such as income inequalities, unemployment, etc., and; (iii) critics also believe that practicability is an essential consideration in every tax proposal, if a tax cannot be collected; it is of no use to impose it. However, a choice has to be made with reference to their possible effects on the working of the economy.

\subsubsection{Ibn-Khaldun's Theory of Taxation}

This theory was propounded by Ibn Khaldum's in 1345 . The theory of taxation was based on the need to lower as much as possible the amounts of tax levied upon persons capable of undertaking cultural enterprises. In this manner, such persons will be psychologically disposed to undertake them, because they can be confident of making profit from them. Therefore, he advocated for decreasing the burden of taxation on enterprises and producers, in order to encourage them by ensuring greater profits to entrepreneur and revenue to the government. He opined that when the tax assessments and imposts upon subjects are low, the latter will have energy and desire to do things. As enterprises grow and increase, because the low taxes bring satisfaction, and when the enterprises grow, the number of individual imposts and assessments amounts also grow. In consequence, the tax revenue, which is the sum total of the individual assessments increases. Ibn-khaldun's theory of taxation has been considered one of Ibn khaldun's most important contributions to economic thought. Gwartney [22], supports the work of Ibn Khaldun [18] when he opined that empirical studies of tax cuts that took place in USA during the twenties, sixties and eighties support Ibn Khaldun's theory of taxation and show that it is still vital and well-suited if similar conditions are found. Gwartney [22] opined further that 'Prodded by Secretary of the Treasury Andrew Mellon, three major tax cuts introduced by the USA Secretary of the Treasury Andrew Mellon, reduced the top marginal tax rate from 73 percent in 1921 to 25 percent in 1926 . In addition, the tax cuts eliminated or virtually eliminated the personal income tax liability of low-income recipients. The results were quite impressive he noted and the economy grew rapidly from 1921 through 1926. He went further to say that after the rates were lowered, the real tax revenue collected from taxpayers with incomes above $\$ 50,000$ rose from $\$ 305.1$ million in
1921 to $\$ 498.1$ million in 1926 which was an increase of 63 percent.

\subsection{Empirical Review}

Twesige and Gasheja [52] analyzed the effect of tax incentives on the growth of sales of SMEs from 2013 up to 2018 in Kenya, where the sales were said to be increasing year to year. Based on these results from the sampled SMEs financial statements, the financial performance of the SMEs was good. Since, profitability is said to be a measure of the amount by which a company's revenues exceeds its relevant expenses, the results of their study revealed that the availability of tax incentives led to an increase in the sales during the study period. This means that tax incentives have a positive effect on the growth of sales of SMEs The findings of Twesige and Gasheja [42] relates to the study carried out by Külter and Demirgüneş [29] who pointed out that sales revenue and profitability of SMES are affected significantly by tax incentives. Mayende [32] study on the 'Effects of Tax Incentives on Firm Performance' analyzed the effects of tax incentives on the performance of Ugandan manufacturing firms in terms of gross sales and value added employing panel data estimation techniques. The study findings show that firms with tax incentives perform better in terms of gross sales growth and value added than their counterparts. The study thus concluded that Government needs to streamline the provision of tax incentives for better firm performance. Isaac [25] investigated the effects of government taxation policy on Uasin Gishu County, Kenya SMEs sales revenue. The study adopted an exploratory research design. The data for the study were generated from secondary and primary sources, the primary data were extracted by administering 180 questionnaires, personal interviews and document analysis. The research findings showed that government tax policy has a direct significant impact on SMEs sales revenue. Furthermore, the study revealed that the effects of the government taxation policy on SMEs sales revenue could either be positive or negative. The study concluded that the SMEs should be levied lower amount of tax payable in order to allow for them to have as much as necessary funds for other activities that will lead to growth in their business and yield profitability.

\subsection{Justification for the Study}

Since SMEs dominate the private sector in most developing countries such as Nigeria, a deeper understanding of how government tax incentives contribute to growth in sales revenue of SMEs is important and cannot be overemphasized. High tax imposition on the SMEs might lead to increase in cost of production and thus make their products uncompetitive and may lead to reduced sales revenue. The reduced sales revenue might lead of death of the business. Aremu and Adeyemi [6], were of the view that most SMEs in Nigeria die within their first five years of existence, a smaller percentage goes into extinction between the sixth and tenth year while only about five to ten percent survive, thrive and 
grow to maturity. However, SMEs remain the foundation as well as the building block in the realization of any meaningful and sustainable growth in an economy and are major contributors to the GDP [53]. Therefore, in a bid to maintain rapid growth among small and medium enterprises, fiscal incentives become a vital tool of government investment promotion strategy. These states are dominated by "civil servants", less industrialized and thus requires this study to bring the attention of the governments to the need to stimulate the growth of SMEs in the states through the use of tax incentives in order to improve the GDP of the states currently ranked as number 13 and 33 among the 36 states in Nigeria by the Nigerian Bureau of Statistics [48]. Despite of the importance of sustaining the growth of SMEs as a way of boosting the country's economy, studies solely focusing on the effect of tax incentives on the growth of sales revenue of SMEs businesses in developing countries particularly Nigeria as it relates to Ondo and Ekiti States seem to be very limited and scarce. For instance, Atawodi and Ojeka [9] research was on "Relationship between Tax Policy, Growth of SMEs and The Nigerian Economy". The research found a negative relationship between tax and a small business ability to sustain itself rather on how tax incentives affect the growth of SMEs. Moreover, the study failed to explain the indices used in measuring the growth of SMEs in the study. Agwu [4] was on "Issues, Challenges and Prospects of SMEs in Porthacourt City, Nigeria". Udofot and Etim [53] in the other hand, was on "The Effect of Tax Revenue Components from SMEs on the Economic Growth of Nigeria from 1980-2015". Also, Agot and Ugwuoke [3] study was on "Taxation and Growth of SMEs in Nigeria: A Case Study of Selected SMEs in Nasarawa State". These studies failed to address the issue of tax incentives as they affect the growth of sales revenue of SMEs businesses in Nigeria. Other studies carried out outside Nigeria such as Twesige and Gashega [52] focused solely on tax incentives given to the SMEs investors by the government rather than tax incentives offered to the SMEs businesses. It is within the context of the identified gap that the study will examine the effect of tax incentives on the growth of sales revenue of SMEs businesses in Ondo and Ekiti.

\section{Methodology}

\subsection{Population}

772 structured questionnaires were administered and 669 responses through paper copies were filled and returned from across the six senatorial districts in Ondo and Ekiti States. This represents a response rate of $87.8 \%$. According to Mugenda and Mugenda [32], a response rate of $70 \%$ and above is excellent. Following the assertion of Mugenda and Mugenda [32], the responses rate for this study of $87.8 \%$ is considered sufficient for making inferences and drawing relevant conclusions. Table 3 illustrates the rate of responses from the respondents which made up of the owner/managers, auditors, accountants and employees of the SMEs in the six districts of Ondo and Ekiti states. Data analysis for this study was done in two stages: the descriptive and inferential analysis. The descriptive analysis being the first stage was carried out using percentage denotations and frequencies as well as other descriptive items to show variations in responses and opinions. The second stage which is the inferential analysis was carried out using the multiple regression analysis in SPSS to assess the effect of the independent variable (tax incentives) on the dependent variable (growth in sales revenue of SMEs ) in order to generate estimates such as mean and standard deviations. The hypotheses formulated in the study were also tested using multiple regression. Data analysis was done with the aid of the Statistical Package for Social Sciences (SPSS) Version 21.0 to test the effect of the independent variables on the dependent variable.

The variables for this study operationalized thus:

$$
\mathrm{Y}=\mathrm{f}(\mathrm{X})
$$

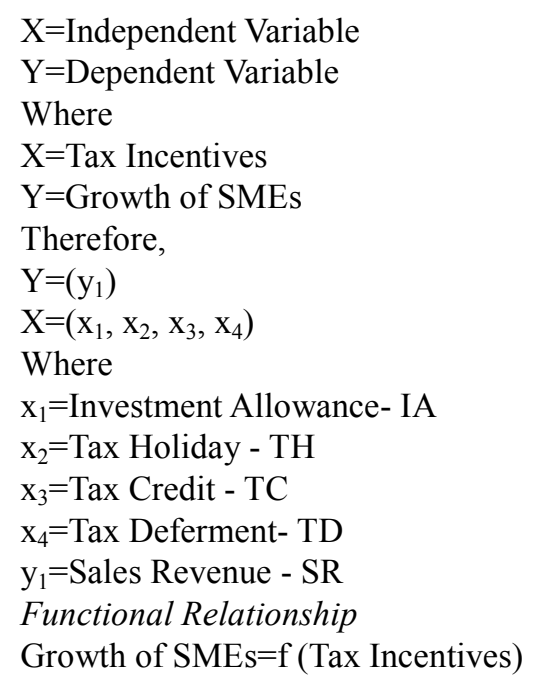

$$
\mathrm{SR}=\mathrm{f}(\mathrm{IA}, \mathrm{TH}, \mathrm{TC}, \mathrm{TD})
$$

Regression Models

$$
\mathrm{SR}=\alpha_{0}+\beta_{1} \mathrm{IA}_{\mathrm{i}}+\beta_{2} \mathrm{TH}_{\mathrm{i}}+\beta_{3} \mathrm{TC}_{\mathrm{i}}+\beta_{4} \mathrm{TD}_{\mathrm{i}}+\varepsilon_{\mathrm{i}}
$$

$$
\text { SMEs Growth }=\alpha_{0}+\beta_{1}(\text { Inv. Allowance })+\beta_{2}(\text { Tax Holiday })+\beta_{3}(\text { Tax Credit })+\beta_{4}(\text { Tax Deferment })+\mu_{\mathrm{i}} \text {. }
$$

Table 3. Response Rate.

\begin{tabular}{lll}
\hline Questionnaire & Frequency & Percentage (\%) \\
\hline Response & 679 & $88 \%$ \\
Non-response & 93 & $12 \%$ \\
Total & 772 & $100 \%$ \\
\hline
\end{tabular}

Source: Research Work (2020). 


\subsection{Researcher's Conceptual Model}

The conceptual model was developed to establish the relationship between the independent variables (Tax
Incentives) and the dependent variable (Sales Revenue of SMEs) as stated in the gap of the study.

\section{Conceptual Model of Tax Incentives and SMES Growth}

Independent Variable

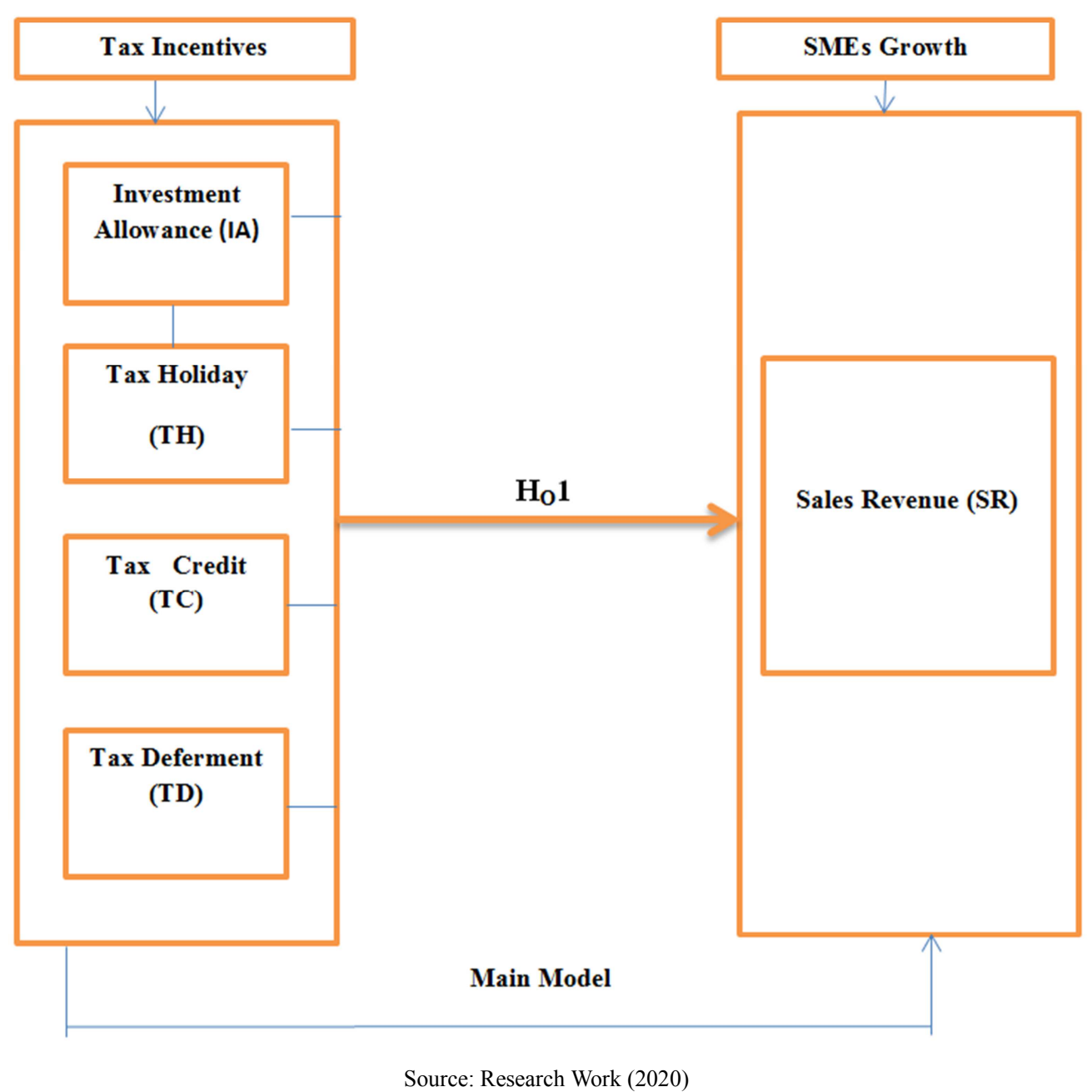

Figure 1. Conceptual Model of Tax Incentives and SMES Growth.

The independent and dependent variables for this research are Tax Incentives (X) and Growth in sales revenue of SMEs (Y) respectively. The independent variable, tax incentives (X) is measured using the following dimensions: investment allowance, tax holiday, tax credit and tax deferment while the dependent variable is measured by sales revenue.

\section{Results and Discussion of Findings}

\subsection{Data Analysis}

Figures $2 \mathrm{~A}, 2 \mathrm{~B}, 2 \mathrm{C}$ and $2 \mathrm{D}$ showed that majority of the respondents $79.5 \%$ were males while $20.5 \%$ were females. For the type or nature of the SMEs, the majority (29.5\%) were providing health and social services while only $7.4 \%$ were into Agric/Agro Allied services. Also, $44.2 \%$ of the SMEs were established between 11-15years ago while only $2.9 \%$ were established more than 21years ago. In the sampled SMEs, 29.5\% had between 10-19 employees, while 5.6\% only had between 40-49 employees. In essence, $71.6 \%$ of the sampled SMEs were Small Scale Enterprises while only $28.4 \%$ were Medium Sized Enterprises. 

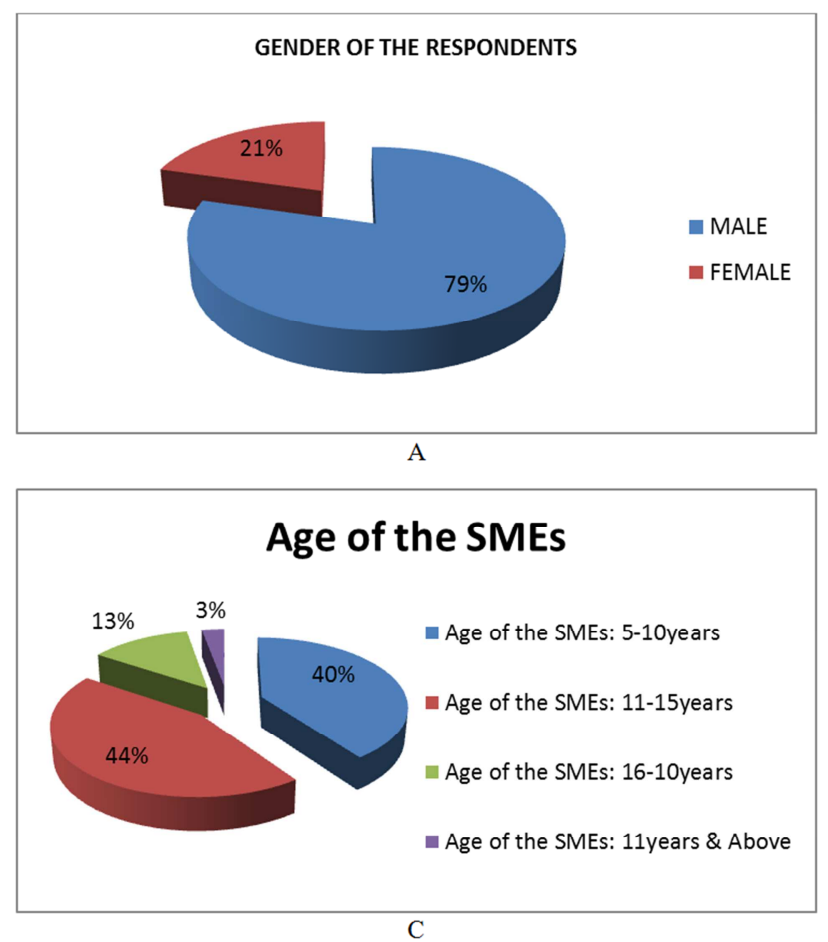

Source: Research Work, 2020

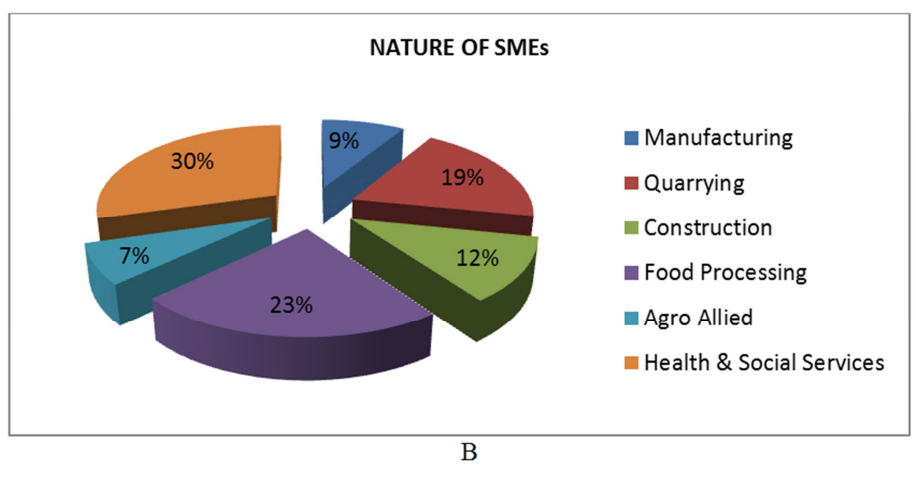

Number of Employees

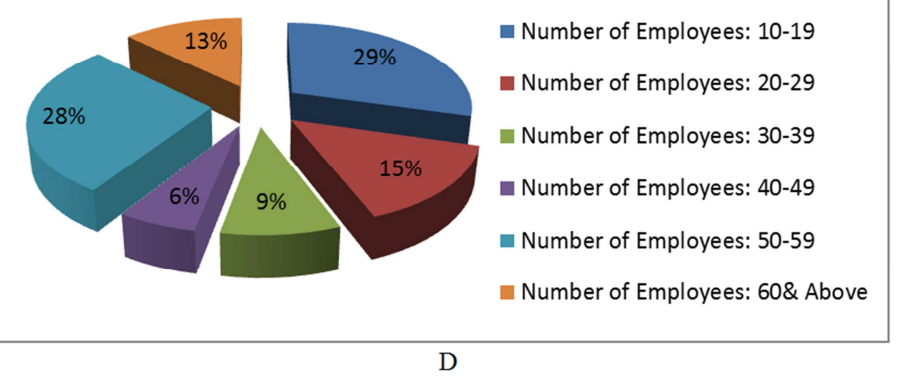

D

Figures 2. A (Gender of the respondents), B (Nature of SMEs), C (Age of the SMEs), and D (Number of Employees), Demographic Characteristics of Respondents.

\subsection{Test of Hypothesis}

Research Objective: evaluate the effect of tax incentives on the growth in sales revenue of SMEs in Ondo and Ekiti States, Nigeria.

Research Question: What is the effect of tax incentives on the growth in sales revenue of SMEs in Ondo and Ekiti States, Nigeria?

Research Hypothesis: There is no significant effect of tax incentives on the growth in sales revenue of SMEs in Ondo and Ekiti States, Nigeria.

Table 4. Regression Estimate.

\begin{tabular}{|c|c|c|c|c|c|}
\hline \multirow{2}{*}{ Model } & \multicolumn{2}{|c|}{ Unstandardized Coefficients } & \multirow{2}{*}{$\begin{array}{l}\text { Standardized } \\
\text { Coefficients }\end{array}$} & \multirow{2}{*}{$\mathbf{t}$} & \multirow{2}{*}{ Sig. } \\
\hline & B & Std. Error & & & \\
\hline (Constant) & .468 & .123 & & 3.796 & .000 \\
\hline Investment & .847 & .029 & .879 & 22.350 & .002 \\
\hline \multicolumn{6}{|l|}{ Allowance } \\
\hline 1 Tax Holiday & .872 & .039 & .904 & 2.102 & .016 \\
\hline Tax Credit & .746 & .042 & .778 & 7.180 & .000 \\
\hline Tax Deferment & .742 & .027 & .774 & 7.238 & .000 \\
\hline \multicolumn{6}{|c|}{$\mathrm{R}=0.872^{\mathrm{a}} ;$ Adjusted $\mathrm{R}^{2}=0.759 ; \mathrm{F}=313.815$} \\
\hline
\end{tabular}

Dependent Variable: Sale Revenue* Significant at 5\%/

Source: Research Work, 2020/

From Table 4 , the regression model equation using unstandardized coefficient is: $\mathrm{SR}=\alpha_{0}+\beta_{1} \mathrm{IA}_{\mathrm{i}}+\beta_{2} \mathrm{TH}_{\mathrm{i}}+$ $\beta_{3} \mathrm{TC}_{\mathrm{i}}+\beta_{4} \mathrm{TD}_{\mathrm{i}}+\varepsilon_{\mathrm{i}}$

$$
\mathrm{SR}=0.468+0.847 \mathrm{IA}+0.872 \mathrm{TH}+0.746 \mathrm{TC}+0.742 \mathrm{TD}
$$

The regression estimates of the model show that tax incentives measured by investment allowance (IA), tax holiday (TH), tax credit (TC) and tax deferment (TD) positively affects growth of SMEs measured by sales revenue $(\mathrm{SR})$. This is indicated by the signs of the coefficient $(\beta 0=0.468 ; \beta 1=0.847 ; \beta 2=0.872 ; \beta 3=0.746$ and $\beta 4=0.742)$. Also, investment allowance has a strong positive significant effect on sales revenue $(\beta=0.847, t=22.350, p=0.02)$, tax holiday has a positive significant effect on sales revenue $(\beta=0.872, t=2.102, p=.016)$, tax credit has a strong positive significant effect on sales revenue $(\beta=0.872, t=7.180, p=.000)$ and tax deferment also has a positive significant effect on sales revenue $(\beta=0.746, t=7.238, p=.000)$. The Adjusted $R 2$ of the model showed that $75.9 \%$ of the variations in sales revenue of SMEs could be attributed to tax incentives proxies used in this study, while the remaining $24.1 \%$ of the variations in sales revenue of selected SMEs are caused by other factors not included in this model. The overall FStatistics is 313.815 , while the P-value of the F-Statistics is 
0.000 which is less than 0.05 adopted for this work. The study rejected the null hypothesis, implying that tax incentives have a significant effect on the growth in sales revenue of SMEs in Nigeria.

\subsection{Discussion of Findings}

The purpose of this study was to determine the effect of tax incentives on the growth in sales revenue of SMEs in Ondo and Ekiti States, Nigeria. Primary data were used for the analysis. From the inferential regression analysis, the following were the findings: The model one summary shows that the adjusted coefficient of determination is 0.759 . This indicates that $75.9 \%$ variation in sales revenue is attributable to availability of tax incentives as proxy by investment allowance (IA), tax holiday (TA), tax credit (TC) and tax deferment (TD). While the remaining $24.1 \%$ variation in growth in sales revenue of SMEs can be attributed to other variables not covered in this model. Investment allowance has a strong positive significant effect on sales revenue ( $\beta=0.847, t=22.350, p=0.02)$, tax holiday has a positive significant effect on sales revenue $(\beta=0.872, t=2.102, p=.016)$, tax credit has a strong positive significant effect on sales revenue $(\beta=0.872, t=7.180, p=.000)$ and tax deferment also has a positive significant effect on sales revenue $(\beta=0.746$, $t=7.238, p=.000)$. The findings of the study substantiate the findings of Isaac [25] who investigated the effects of tax incentives on Uasin Gishu County, Kenya SMEs sales revenue. The study adopted an exploratory research design. The data for the study were generated from secondary and primary sources, the primary data were extracted by administering 180 questionnaires, personal interviews and documentary analysis. The research findings showed that tax incentives has a direct significant impact on SMEs sales revenue. The study further revealed that the effect of tax incentives on SMEs sales revenue could either be positive or negative. The study submitted that the SMEs should be granted tax incentives in order to allow them to have as much as necessary funds for other activities that will lead to growth in their business and yield profitability. Similarly, Afshari, Adabili, and Ali [7] used sales personnel number, age, array of products as growth indices to analyze the effect of tax incentives on SMEs growth. The findings of the analysis revealed that tax incentives have a noteworthy relationship with all the dimensions used to measure growth.

Also, the findings of this research also aligned with the study of Twesige and Gasheja [52] that analyzed the effect of tax incentives on the growth of sales revenue of SMEs from 2013 up to 2018 in Kenya, where the sales were said to be increasing year to year. Based on these results from the sampled SMEs financial statements, the financial performance of the SMEs was good. Since, profitability is said to be a measure of the amount by which a company's revenues exceeds its relevant expenses, the results of their study revealed that the availability of tax incentives led to an increase in the sales during the study period. This means that tax incentives have a positive effect on the growth of sales of SMEs. Külter and Demirgüneş [29] also pointed out that sales revenue and profitability of SMEs are affected significantly by tax incentives. Mayende [32] study on the 'Effects of Tax Incentives on Firm Performance' analyzed the effects of tax incentives on the performance of Ugandan manufacturing firms in terms of gross sales and value added employing panel data estimation techniques. However, in contrast, the study of Atawodi and Ojeka [9] using sustenance and expansion as indices of SMEs growth to ascertain whether a relationship exists between tax incentives, the SMEs' growth, and the Nigerian economy found that there was a considerable negative relationship existing between tax incentives and businesses' capability to keep going and make itself bigger (in terms of profitability, revenue growth, and turnover).

\subsection{Implications of Findings}

Findings from descriptive and empirical analysis have some implications for industry, society, government and management practice in the SME sector. Each implication is discussed subsequently.

\subsubsection{Implications to Government}

The findings of the study had shown how well tax incentives influenced the growth of SMEs in the areas of sales revenue. Hence, it implied the need for government on the provision of good fiscal policies which would enhance the growth of SMEs in Nigeria. It helped government in addressing impediments to the growth of SMEs through the formulation of right fiscal policies towards SMEs development in Nigeria. Government would also be able to identify the importance of small and medium enterprises sector in the achievement of economic development and national growth in Nigeria.

\subsubsection{Implications to Industry}

The results of this study basically suggested that tax incentives have positive significant effect on sales revenue of SMEs. Hence, appropriate fiscal policies and tax incentives are critical factors in the growth of SMEs and enhance their operational efficiency in the areas of sales revenue. At present, the existing taxation policy does not support the dynamism and operational expansion of the SMEs. Therefore, the study implied that SME sector would now be able to exploit all incentives available to it in the area of taxation as a way to boost operations. SMEs now get exposed to various government tax incentives available to the business.

\subsubsection{Implications to Society}

With the SMEs being unable able to achieve a sustainable growth in sales, due to high tax rates, the study's findings had the implications that with the availability of tax incentives to the SMEs, it would lead to expansions and thus enable the SMEs to contribute to the improvement of the economy. Hence, the SMEs would grow more, continue in the provision of employments and therefore would serve as a significant driver of poverty eradication in Nigeria. 


\section{Conclusion and Recommendation}

\subsection{Conclusion}

From the analysis conducted, the following conclusions were made:

There is a significant effect of tax incentives on the growth of SMEs in Ondo and Ekiti States with regard to sales revenue. This is manifested by the positive association that was found the explanatory and the dependent variables through empirical analysis. In addition, the coefficient of determining value that was gotten in the analysis affirmed the conclusion that tax incentives have a significant effect on sales revenue. This is evident from the coefficient of $+0.468+0.847+0.872+0.746$ +0.74 . The adjusted $R^{2}$ model shows $75.1 \%$ variations in growth in sale revenue (GSR) was attributed to tax incentives measured by IA, TH, TC and TD while the remaining $24.1 \%$ was caused by other explanatory factors outside this model, the p-value of its F-statistics of 0.000 which is less than the acceptable 0.05 level of significance; implying that the model is statistically significant. This study therefore concluded that tax incentives are important predictors of the growth of SMEs in terms of sales revenue.

\subsection{Recommendations}

Emanating from the findings, conclusions and contributions of the study, the below recommendations were made: Government should address the dire need for start-up funds for SMES by providing incentives for SMEs funding. The SMEs industry players should enlighten themselves appropriately on the form of business they want to embark upon before venturing into it to make them better equipped by going for entrepreneurial training programs. The government should employ tax holiday as a major tax incentives for newly established small and medium enterprises because it stimulates their investing power. Government should promote the growth of small and medium enterprises by creating the necessary enabling frameworks and relax the burden of regulating measures and ensure that their efforts are geared towards granting tax incentives to small and medium enterprises. Government should create adequate awareness through the tax authorities to explain the role of taxation on development and help small and medium enterprises to understand tax laws in Nigeria.

\subsection{Contribution to Knowledge}

Taking into cognizance the nature of the study, there were a number of ideas and concepts that formed the various contributions that this current study made to the knowledge base of tax incentives along with measures of growth of SMEs. These contributions were made in the area of empirics, concepts, theories, literature, accounting practices and policy.

Although there had been a range of compilations of empirical studies in the areas of tax incentives and the growth of SMEs, nonetheless this article contributed to the existing knowledge by adding another empirical work on subvariables on both tax incentives factors and SMEs growth indicators (such as, tax incentives- investment allowance, tax holiday, tax credit, tax deferment- sales revenue).

As regard contribution to concepts, this study proposed, the inclusion of different tax incentives- SMEs growth dimensions that served as additional factors to existing literature. A good number of studies in the past had focused on tax incentives- SMEs growth with no sub variables to indicate what effect an individual sub variable can have on the other dimension. However, the work of Twesige and Gasheja [52] brought it clear that some sub-variables when combined together could enact different findings. Therefore, the conceptual model of this study brought the different variables under tax incentives and SMEs growth measures together which included the explanatory, dependent and subvariables. The current study thus reviewed concepts of tax incentives such as investment allowance, tax holiday, tax credit and tax deferment. The concept of SMEs growth indicator such as sales revenue was also reviewed.

The tax incentives dimensions were anchored on four taxation theories namely the benefit theory, the ability to pay theory, the expediency theory and Ibn-Khaldum theory of taxation which served as contributions to knowledge. To link the need for tax incentives and the growth of SMEs, the IbnKhaldun's theory of taxation was adopted. This was because the theory advocated for a low tax rate in order to stimulate the growth of enterprises. According to Ibn-Khaldun [23], it is the nature of government spending and its policy of taxation that determine whether the economy is passing through the period of formation, prosperity and stability, or depression and decay. If the tax policy is favourable, it shows that prosperity and stability. Furthermore, the theory pointed out various principles of taxation, such as equity and efficiency, justice and neutrality, ability to pay, economy, benefit and convenience, attributed to Adam Smith, multiplier effect of government spending, incidence of taxation, in addition to a number of fundamental economic theories.

The study contributed to the body of knowledge in that it improves on the existing research by testing sub- variables from the main variables in the study. The study also adopted the multiple regressions in analyzing these sub-variables in order to determine their individual effects. The study also empirically contributes to research by reviewing various articles with regard to tax incentives and SMEs growth which will serve as a reference point to other intending researchers who might want to consider other measures of tax incentives and SMEs growth.

The study contributed to accounting practices in that it availed the accounting practitioners and bodies to regularly assess the tax burden on profits to determine if the tax system is supportive of investment. It also allows the accounting bodies and practitioners to understand statutory provisions and the effect of tax planning strategies such as the transfer pricing and thin capitalization on the business growth and would be able to provide professional advices. It would help the accounting practice in the area of training and continuous education of members in practice on various fiscal incentives that aid business growth. 
Furthermore, there had been several studies in the area of government tax policy and fiscal incentives; nevertheless, this article contributed to policy in that aside from the back end incentives given enterprises, front end incentives can also be made available to prospective investors in order to encourage direct investment both foreign and domestic.
These incentives can include (i) reduced capital gain taxes on SMEs equity investments and (ii) deduction of a set percentage of the value investors invest in shares of SMEs. This can be done via offering tax offsets only for acquiring shares in new SMEs equity offerings.

\section{Appendix}

Questionaire

Tax Incentives and the Growth in Sales Revenue of Small and Medium Enterprises Questionnaire (TIGSRSMEQ).

\section{Appendix A: Enterprise Characteristics}

(1) Business Nature of the enterprise: Manufacturing Construction Agro-Allied

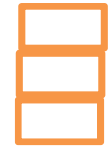
Mining and Quarrying Food Processing Others specify

(2) Age of the enterprise: 5-10 years

(3) Number of Employees: 10-19 $50-59$

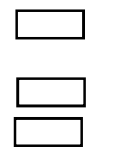

11-15 years

20-29 60 and above

Health and Social Services

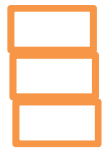

21 years \& above

$40-49$

(4) Current Value of Assets: \#1 million or less \#100million or less

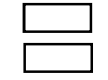

\#50million or less $\# 150$ million or less

$16-20$

$30-39$

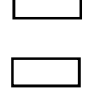

(5) Annual Sales Revenue (\#):

(6) Annual Gross Margin (\#):

(7) Annual Retained Earnings (\#)

\section{Appendix B: Personal Characteristics}

Please indicate by ticking

(8) Gender: Male

(9) Age: 21-30 years 51-60 years

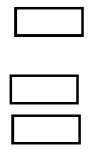

Female

31- 40 years 61years and above

(10) Educational Qualification: O/L

ND

(11) MA/M. Sc

M. Phil/ Ph. D

(12) Number of years in the Enterprise: 1-5 years

\section{Appendix C: Independent Variables}

A: Investment Allowance (IA)

SA $\quad$ A $\quad$ U D

The enterprise has experienced growth in sales revenue due to gains made from investment allowance.

The utilization of investment allowance has improved the enterprise profits in the last five years.

Savings made from investment allowance earned has led to increase in the enterprise tangible assets

Investment allowance enhances the enterprise ability to retain earnings for business expansion.

The investment allowance available to the enterprise is affected by tax rate. 
B: Tax Holiday (TH)

SA A U D SD

16 The enterprise earns more sales revenue as during tax fee period

17 Tax holiday leads to reduction in the enterprise operational costs

18 The enterprise earns more profits during the tax free period.

19 Do you agree that the enterprise retains more earnings during tax free period?

20 The enterprise is able to invest in tangible assets more during tax holiday period

C: Tax Credit

SA A U D $\quad$ SD

21 The enterprise experienced increase in sales revenue due to tax credit enjoyed

22 The enterprise is able to invest in assets as a result of tax credit enjoyed

23 Tax credit enjoyed by the enterprise has led to increase in gross margin

Do you agree that the enterprise is able to retain more earning from profit when given tax credit?

D: Tax Deferment (TD)

25 The enterprise is able to expand its investment without current tax obligation.

26 The enterprise is able to earn more profits when tax is deferred.

27 The enterprise experiences more sales when tax is deferred.

The tax that could have been paid is invested in tangible assets for business expansion when tax is deferred.

\section{Appendix D: Dependent Variable}

F: SMEs Growth

Sales Revenue (SR)

SA A U D

There is a notable increase in the amount realized from the sales of goods and services in the enterprise.

30 This SME accomplishes its annual sales revenue target.

31 The firm's annual sales revenue exceeds expectations.

32 There is satisfaction with sales revenue by the enterprise

\section{References}

[1] Abdulrahman, S. \& Kabir, M. K (2017). Tax incentive as a real modifier for industrial growth and development in Nigeria. International Journal of Development Strategies in Humanities, Management and Social Sciences, 4 (2), 1416.

[2] Adamu, S. (2014). The impact of tax incentives on economic growth and industrial development in Nigeria. International Journal of Advanced studies in Economics and Public Sector Management, 2 (1), 13-14.
[3] Agot, G., J. \& Ugwuoke, O. W. (2018). Taxation and the growth of small and medium scale enterprise (SMEs) in Nigeria: A Case of Selected SMEs in Nasarawa State. International Journal of Advanced Research in Accounting, Economics and Business Perspectives, 1 (2), 10-27.

[4] Agwu, M. O (2014). Issues, challenges and prospects of small and medium scale enterprises (SMEs) in Port-Harcourt city, Nigeria. European Journal of Sustainable Development, 3 (1), 101-114.

[5] Ariyo, D. (2005). Small firms are the backbone of the Nigerian Economy. African Economic Analysis, Academy Management Journal 1 (1). 
[6] Aremu, M. A. \& Adeyemi, S. A. (2011). Small and medium scale enterprises as a survival strategy for employment generation in Nigeria. Journal of Sustainable Development, Canadian Center of Science and Education, 4 (1), 23-40.

[7] Afshari, R., Ardabili, F. S. \& Ali, S. (2012). Do government financial and tax policy affect SMEs growth? Life Science Journal, 9 (4), 4154-4159.

[8] Audretsch, D. (2010). Dynamic role of small firms: Evidence from the US. World Bank Institute, 2001-2037.

[9] Atawodi, O. W. \& Ojeka, S. A. (2012). Relationship between tax policy, growth of SMEs and the Nigerian economy. International Journal of Business and Management, 7 (13), 111.

[10] Bhartia, H. L. (2009). Public Finance (14th Ed). New Dheli: Vikas Publishing House.

[11] Basil, A. N. (2005). "Small and Medium Enterprises (SMES) in Nigeria: problems and prospects" (Unpublished Ph. D. Thesis) submitted to Department of Business Administration, St. Clements University.

[12] Bergner, S. M. \& Heckemeyer, J. H. (2017), Simplified Tax Accounting and the Choice of Legal Form, European Accounting Review.

[13] Broersma, L. \& Gautier, P. (2017). Job creation and job destruction by small firms: An empirical investigation for the Dutch manufacturing sector. Journal of Small Business Economics 9 (3), 211-224.

[14] Buehler, I. L. (2006). Tax administrations and SME in developing countries: SME department World Bank Group; 2005.

[15] Chapra, M. U. (2000). The Future of Economics: an Islamic Perspective, Leicester, the Islamic Foundation.

[16] Companies and Allied Matters Act (CAMA) 1990 as amended 2004. The Nigerian regulatory framework for companies.

[17] De-Wit, G., \& De-Kok, J. (2014). Do small businesses create more jobs? New evidence for Europe. Journal of Small Business Economics 42 (2), 283-295.

[18] Egbesola, F. (2018, December 5). SMEs seek tax relief, ease of business climate. The Nation Newspaper. Retrieved from http://www.thenationsonlineng.net/author/.

[19] Ekpenyong, D. B., \& Nyong, M. O (2012). Small and medium- scale enterprises in Nigeria: Their Characteristics, Problems and Sources of Finance. African Economic Research Consortium.

[20] Fatai, A. (2011). "Small and Medium Scale Enterprises in Nigeria: The Problems and Prospects". Retrieved January15fromwww.thecje.com/journal/index.php/economicsj ournal/article/.../8.

[21] Feyitimi, O., Temitope, O. A., Akeem, L. B. \& Oladele, O. S. (2016). Tax incentives and the growth of small and medium scale enterprises in developing economy: The Nigerian Experience. European Journal of Research and Reflection in Management Sciences, 4 (2), 1-19.

[22] Gwartney, J. D. (2006). Supply-Side Economics. Retrieved $15^{\text {th }} \quad$ September $\quad 2019$ from http://www.econlib.org/LIBRARY/Enc/SupplySideEconomics .html
[23] Ibn-Khaldun (1345). Ibn Khaldun's Theory of Taxation.

[24] Ibrahim, H. A. (2015). Analysis of impact of credit on the performance of SMEs in Sokoto metropolis of Sokoto State of Nigeria. International journal of small business and entrepreneurship research, 3 (4), 22-31.

[25] Issac, K. K. (2015). Effects of government taxation policy on sales revenue of SME in Uasin Gishu County, Kenya. International Journal of Business and Management Invention, 4 (2), 29-40.

[26] Kaplan, D. (2011). Rethinking government support for business sector R\&D in South Africa: the case for tax incentives. South African Journal of Economics 69 (1), 72-92.

[27] Keen M (2013). Taxation and development: Critical issues in taxation and development. Cambridge: MIT Press.

[28] Kongolo, M. (2010). Job creation versus job shedding and the role of SMEs in development African Journal of Business, 4 (11), 2288-2295.

[29] Külter, B. \& Demirgüneş, K. (2007). Determinants of profitability in retailing firms: An empirical study on ISE listed retailing firms. Journal of Çukurova University and Institutions of Social Sciences 2 (34): 445-460.

[30] Liu, S. (2018), Empirical analysis of cash dividend payment in Chinese listed companies, Nature and Science, 3 (1), 65-70.

[31] Machek, O., \& Machek, M. (2014). Factors of business growth: A Decomposition of Sales.

[32] Mayende, S. (2013). The Effects of tax incentives on firm performance: Evidence from Uganda. Journal of Politics and Law, 6 (4), 87-102.

[33] MINECOFIN (2017). The Rwanda investment board provides tax incentives. Kigali: MINECONFIN. Retrieved September 2019, from http://www.minecofin.gov.rw/index.php?id=2.

[34] National Bureau of Statistics (NBS) (2018). Official Report, Abuja, NBS Publications.

[35] Nwakoby, N. P., Ajike, A. K., \& Ezejiofor R. A. (2017). SMEs financing and economic development: Nigerian Government incentives (1999-2015). Scholars Journal of Economics, Business and Management, 4 (8B), 548-554.

[36] Ocheni, S. I., \& Gemade, T. I. (2015). Effect of multiple taxation on the performance of small and medium scale businesses in Kogi State. Journal of Academic Research in Business and Social Review, 5 (3), 345-364.

[37] Okauru, I, O. (2009). How corporate Nigerians can maximize on the provisions of tax incentives for private sector contribution to sports development in Nigeria. Paper Presented at the National Sports Commission Stakeholders Conference Abuja, Nigeria. Retrieved from http://www.iosrjournals.org/paper.pdf.

[38] Okonkwo, N. O., \& Obidike, C. P. (2016). Small and medium scale enterprises financing in Nigeria: Problems and prospects. International journal of innovative sciences and Humanities Research 4 (1), 77-86.

[39] Olaleye, M. O, Memba, F. S. Riro, G. K, (2015) Capital allowances and foreign direct investment in listed manufacturing companies in Nigeria: Research Journal of Finance and Accounting 6 (24). 
[40] Oyedele, T. \& Erikume, K. (2015) Tax data code Nigeria pricewatercoopers tax academy 17 (1), 4-7.

[41] Ojochogwu, W. A. \& Ojeka, S. A. (2012). Relationship between tax policy, growth of SMEs and the Nigerian economy. International Journal of Business and Management, 7 (13), 125-132.

[42] Peace, N., Ajike, A. K. \& Ezejiofor, R. A. (2017). SME financing and economic development: Nigerian Government Incentives (1999-2015). Scholars Journal of Economics, Business and Management, 4 (8B), 548-554.

[43] Smatrakalev, G. (2006). Tax policy for small and medium enterprises. Paper delivered at the 6th Global conference on business and economics. Gutman Conference Center, U.S.A.

[44] SMEDAN (2010). Survey Report on Micro, Small and Medium Enterprises (MSMEs) In Nigeria: 2010 National MSME collaborative Survey Retrieved September 2019, from: http://smedan.gov.ng/images/collaborative\%20survey\%20repo rt.smedan-nbs.pdf.

[45] SMEDAN (2013). Survey Report on Micro, Small and Medium Enterprises (MSMEs) In Nigeria: 2010 National MSME collaborative Survey Retrieved September 2019, from: http://smedan.gov.ng/images/collaborative\%20survey\%20repo rt.smedan-nbs.pdf.

[46] SMEDAN (2015). Survey Report on Micro, Small and Medium Enterprises (MSMEs) In Nigeria: 2010 National MSME collaborative Survey Retrieved September 2019, from: http://smedan.gov.ng/images/collaborative\%20survey\%20repo rt.smedan-nbs.pdf.
[47] SMEDAN (2017). Survey Report on Micro, Small and Medium Enterprises (MSMEs) In Nigeria: 2010 National MSME collaborative Survey Retrieved September 2019, from: http://smedan.gov.ng/images/collaborative\%20survey\%20repo rt.smedan-nbs.pdf.

[48] SMEDAN (2018). SMEDAN and National Bureau of Statistics collaborative survey: Selected Findings.

[49] Soyode, L. \& Kajola, S. O. (2006). Taxation: Principles and Practice in Nigeria (1st Ed). Ibadan: Silicon.

[50] Taiwo, J. N., \& Falohun, T. O. (2016). SMEs financing and its effects on Nigerian economic growth. European Journal of Business, Economics and Accountancy, 4 (4).

[51] Teju, S. (2017). Tax Incentive and Made in Nigeria Goods. Economic and Policy Review, 16 (1).

[52] Twesige, D. \& Gasheja, F. (2019). Effect of tax incentives on the growth of small and medium sized enterprises (SMEs) in Rwanda: A Case Study of SMEs In Nyarugenge District. Journal of Accounting and Taxation, 5 (11), 89-98.

[53] Udofot, P. O. \& Etim, E. O. (2017). The effect of tax revenue components from SMEs on the economic growth of Nigeria from 1980-2015.

[54] Uwuigbe, U., Uwuigbe O. R., Adeyemo K. \& Anowai, N. C. (2016) Tax incentives and the growth of manufacturing firms in Nigeria. The Social Sciences Journal, 11 (7), 11-16.

[55] Xinhu (2018). State council unveils policy support for SMEs growth. Retrieved September, 2019, from: https:// www.china.cn/business. 